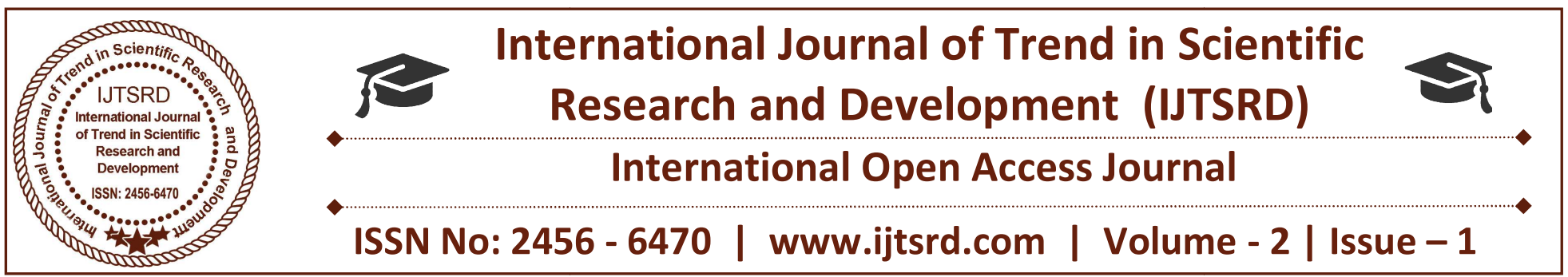

\title{
Doppler Sodar Observations of the Diurnal Variations of the Atmospheric Boundary Layer over Gadanki, a Tropical Rural Station
}

\author{
D. Sharmila \\ Department of Electronics and Instrumentation \\ Technology, Acharya Nagarjuna University, Guntur, \\ Andra Pradesh, India
}

\author{
M. P. Rao \\ Department of System design, \\ Andhra University, Visakhapatnam, \\ Andra Pradesh, India
}

\section{ABSTRACT}

Doppler SODAR (Sound Detection and Ranging) is used to measure vertical velocity in order to investigate the diurnal variations in different seasons and their causative processes. Significant diurnal variations are observed in the air motion at Gadanki. This paper outlines the transitory nature of the Atmospheric Boundary Layer (ABL) a few hours before and after the time of sunset as has been studied over a tropical station, Gadanki $\left(13.45^{\circ} \mathrm{N}\right.$, $79.18^{\circ} \mathrm{E}$ ). With regard the afternoon transition (AT), variation is seen in temperature $(\mathrm{T})$ and wind variance ( $\sigma$, ws), about $100 \mathrm{~min}$ prior to the time of the local sunset, then in the vertical temperature gradient and finally in water vapour mixing ratio. Aloft, both signal-to-noise ratio (SNR) and spectral width $(\sigma)$ show the AT almost at the same time. The start time of the transition shows some seasonal variation, with delayed transitions occurring mostly during the rainy and humid seasons of the northeast monsoon. Updrafts are observed in the afternoon hours in the lower ABL in all seasons whereas downdrafts are observed in the evening hours in the lower ABL during the same. The diurnal and seasonal variations of the measured convective boundary layer over this tropical station are discussed.

Key words: Sodar, ABL, Diurnal

\section{INTRODUCTION}

The Atmospheric Boundary Layer (ABL) is the lowest layer of the atmosphere in which surface forces play a prominent role (Stull, 1988). SODAR is a

widely used remote sensing instrument in the atmospheric boundary layer (ABL) studies. Sodar systems work by transmitting acoustic pulses into the atmosphere and by detecting the Doppler shift in the backscattered signal. Sodar sends and receives successive pulses of sound in different directions with different off-zenith angles. By measuring the intensity and frequency (Doppler shift) of the returned signal as a function of time, the radial velocity and thermal structure of the atmosphere can be determined.

One of the significant features of the ABL is its diurnal variation which controls the transport process. The tropical regions have a very strong diurnal variation being the hottest regions. Which will help in the formation of large organized convective clouds of all sizes as part of the inter-tropical convergence zone. Strong solar fluxes, land-sea-atmosphere contrasts of tropical regions cause ABL to become more dynamic. The ABL during the transition from a well-mixed layer during the day to a stably stratified layer during the night is quite complex and is also poorly understood. In recent years, the phenomena of the afternoon transition (AT) and evening transition (ET) of the ABL have gained attention for various reasons (Lothon et al., 2014). These transitional regimes are found to be important for the vertical transport of species, like pollutants, water vapour and ozone (Klein et al., 2014), the inception and strength of the nocturnal low-level jet (LLJ) (Mahrt, 1981; Van DeWiel et al., 2010), and the whole structure of the nocturnal boundary layer. Furthermore, identification of the $\mathrm{ABL}$ becomes uncertain and there is no 
consensus on which scaling law (day-time convective scaling due to surface buoyancy flux or nocturnal boundary layer scaling due to surface wind stress) would work well during this period (Pino et al., 2006).Furthermore, the start time of the transition and its duration could be different at the surface and aloft because the turbulence may not immediately dissipate after sunset (Busse and Knupp, 2012).

The temperature in this layer differs diurnally and seasonally, which further alters the pressure that results in the fluctuation of the wind. The pace of the wind rises along with height; and its path is disordered because of the topographical environment (Taylor \& Garratt, 1996).Usually, ABL altitude shows high diurnal difference during the monsoon and the post-monsoon months, and being relatively lesser in the pre-monsoon season and the winter. ABL altitude peaks at the noon time during all seasons ( $\sim 1400$ IST) and stays high until the evenings ( 1700 IST) just before sunset. The ABL altitude starts reducing because of the cooling after sunset and attains the lowest level after midnight ( 0200 IST) and commences repeatedly to rise post sunrise $(\sim 0800$ IST). The ABL differs largely from evening to early morning during the monsoon and post-monsoon seasons, as there is greater difference from late midnight to early morning during the pre-monsoon seasons and all through the day in the winter months (Mehta et al., 2017).

Some studies employed models to understand the occurrence of different types of transition (Brazelet al., 2005; Edwards et al., 2006; Pino et al., 2006; Sorbjan,2007; Nadeau et al., 2011; Sastre et al., 2012). Brazelet al. (2005) studied the evening transition under weak synoptic forces that favour the local thermal circulations, and compared the observed transitions with models. In advance,Sastre et al. (2012) determined three types of evening transitions and evaluated the performance of the Weather Research and Forecasting Advanced Research (WRFARW) model in reproducing these transitions by varying PBL parameterization schemes. They noted that all parameterizations reproduced the observed behavior of AT under certain circumstances. Noting the need to understand the transitions in a better way, several field campaigns were conducted in recent years, employing both in situ and remote sensors, exclusively for better characterization and modeling of the transitions of the Boundary Layer Late Afternoon and Sunset Turbulence (BLLAST) (http://bllast.sedoo.fr) (Lothon et al., 2014) and the Phoenix Evening Transition Flow Experiment (TRANSFLEX) (Fernandoet al., 2013). Recently, manned and unmanned aerial vehicles were used to study the vertical structure of the lowest part of the ABL during the AT (Bonin et al., 2013; Lothonet al., 2014).

This paper summarizes the diurnal variation of ABL. The variation of different state variables at the surface and aloft is studied with the help of a case study.

\section{System Description}

The National Atmospheric Research Laboratory (Gadanki) is a tropical rural station located at $\left(13.45^{\circ} \mathrm{N}, 79.18^{\circ} \mathrm{E}\right)$ in South India. This site is located nearly $375 \mathrm{~m}$ above the mean sea level in a rural area in southeastern peninsular India and is surrounded by hillocks (300-800m within a $10 \mathrm{~km}$ region) distributed in a complex fashion. The rainfall in this region is influenced primarily by two monsoons, southwest monsoon (June-September) and northeast monsoon (October-December) (Rao et al., 2009). Phased Array Doppler SODAR installed at NARL is used for the present study; this system has been operating in the frequency range of $1800-2500 \mathrm{~Hz}$ with an acoustic power (output) of $100 \mathrm{~W}$. This system consists of $8 \times 8$ array of antenna elements. With beams tilted from zenith in the east and north directions, all three components of the wind velocities and other scattering parameters (power, signal-tonoise ratio, etc.) between the heights of 30-1500m are determined. Anandan et al (2008) have described the technical specifications of the NARL SODAR system, signal processing, data quality control and preliminary validation of the system data products. The SODAR system technical specifications are shown in table 1.1. 
Table 1.1 Important Technical Specifications of SODAR, NARL.

\begin{tabular}{|l|l|}
\hline Parameter & Specifications \\
\hline Operating frequency & $1.8 \mathrm{KHz}$ \\
\hline Peak power & $100 \mathrm{~W}$ \\
\hline Antenna array & $1 \mathrm{~m} \times 1 \mathrm{~m}$ Phased array \\
\hline Number of elements & 52 \\
\hline Pulse width & $180 \mathrm{~m} / \mathrm{s}$ \\
\hline Inter pulse period $(\mu \mathrm{s})$ & $9 \times 10^{6}$ \\
\hline No. of coherent integrations & 1 \\
\hline No. of incoherent integrations & 1 \\
\hline No. of FFT points & 4096 \\
\hline Beam width $($ deg $)$ & 4 \\
\hline Range resolution $(\mathrm{m})$ & 30 \\
\hline Beam directions & $\mathrm{N} 16, \mathrm{Z}, \mathrm{E} 16$ \\
\hline
\end{tabular}

thermals start to decrease continuously till the sunset

The range-time plots of spectral moments SNR, $\boldsymbol{\sigma}$, WS, $\omega$ from sodar is examined for the clear growth and decay of ABL and convection/precipitation contamination (Grimsdell et al., 2002; Rao et al., 2008). Data from theyear 2010is considered for the present study as a function of the season. Though considerable data were filtered out in the rainy seasons (southwest and northeast monsoons), the number of available days is large enough to represent the season. Measurements from the selected days are used to understand the behavior of AT at different altitudes.

Figure 1 shows the diurnal variation of surface state variables of sodar SNR, horizontal wind speed, $\boldsymbol{\sigma}$, WS, $\omega$ and wind direction on February10, 2010, providing an evolution of the transitional boundary layer at the surface and aloft. The surface state variables exhibit larger variations during the transition period than during the rest of the night. Figure 1shows the transition of the ABL from a highly convective to a more stable regime. The backscatter for Sodar depends on the refractive index irregularities caused primarily by turbulence-driven temperature and humidity variations. The SNR is, therefore, high during the day when the convectively driven turbulence is active. Nevertheless, about 2 hours before sunset, both the intensity and vertical extent of occurs. The minimum backscatter (SNR) is seen just before the sunset, mainly due to the weak turbulence. The magnitude of backscatter and vertical extent of Sodar data again increase in accordance with the deepening of the inversion layer. As noted by Busse and Knupp (2012), the winds within the nocturnal boundary layer generally decrease during the AT, but increase above the nocturnal boundary layer. It makes

the identification of the start time of the AT using wind speed somewhat ambiguous. On the other hand, it is rather easy to identify the start time of the AT from the variations of SNR and $\boldsymbol{\sigma}$. The wind direction does not change much with altitude below $1.5 \mathrm{~km}$ and remains mostly easterly to southeasterly.

The Sodar backscatter, depends primarily on turbulent irregularities of refractive index, decreases with the waning of sensible heat flux (and thermals) during the afternoon transition. On 10 February 2010, the SNR of sodar starts to decrease about $2 \mathrm{~h} 40 \mathrm{~min}$ prior to the time of sunset at all heights. Interestingly, the start time of SNR reduction shows height dependence with higher altitudes showing the reduction earlier. The SNR minimum is observed 10-20 min before sunset at all heights, mainly due to the reduction in turbulent fluctuations in temperature. Nevertheless, the SNR increases again after sunset, following the formation of an inversion layer. 


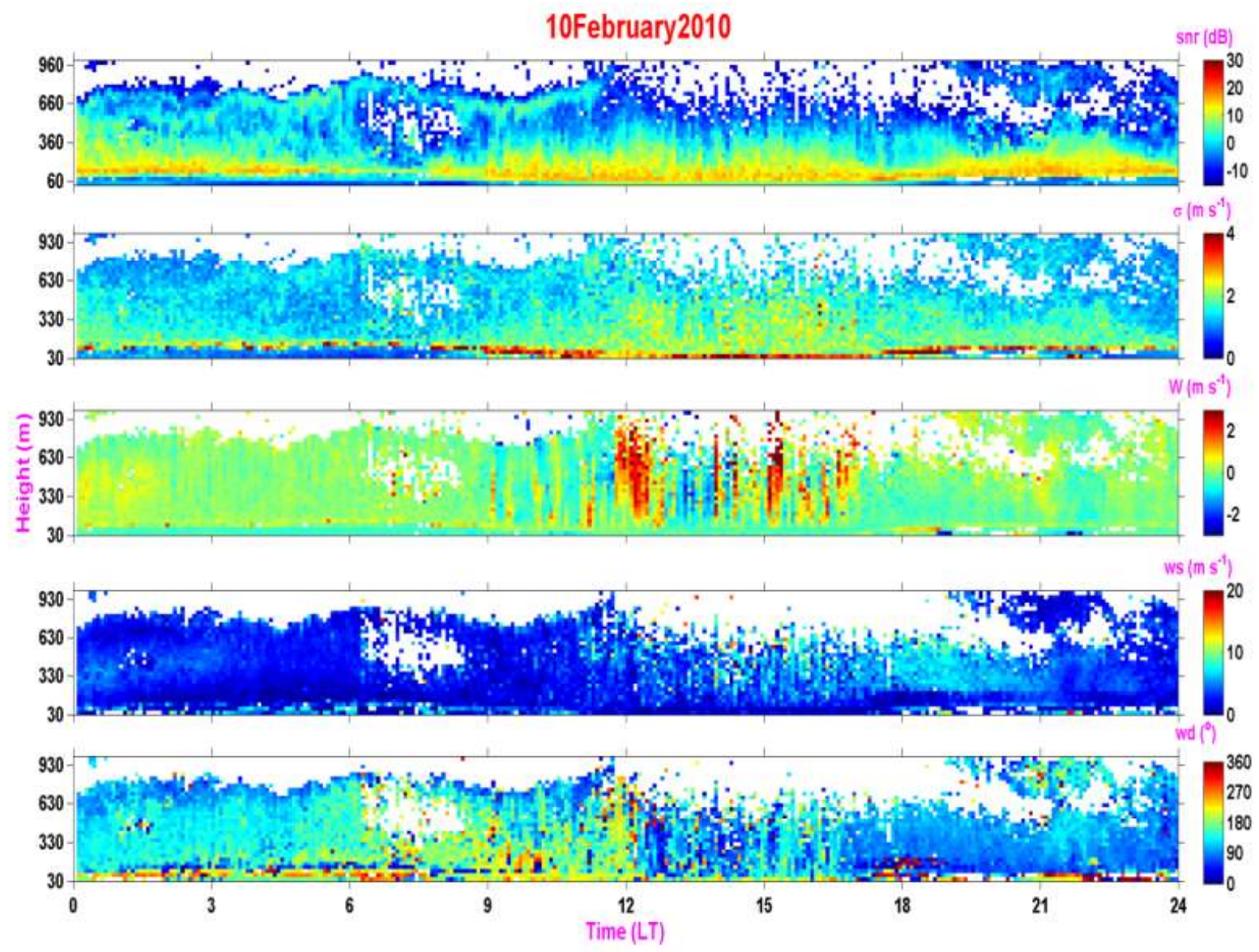

Figure1. Diurnal variation of state variables at the surface and aloft on 10February, 2010, SODAR derived SNR, $\sigma, \mathrm{WS}, \omega$ and WD.

\section{CONCLUSION}

This study presents view of the AT in terms of Doppler Sodar measurements at Gadanki. It receives $55 \%$ of the annual rainfall in the southwest monsoon, raising instantaneous soil moisture levels, the high insulation and temperatures immediately consume the soil moisture for latent heating. On the other hand, this region also gets a good amount of rainfall during the cool northeast monsoon (Rao et al., 2009). The soil moisture levels, therefore, remain high in this season. It is known from earlier studies that the abundance of soil moisture not only produces shallow levels of ABL, but also delays the growth of the ABL (Sandeep et al., 2014). It appears from present observations that not only the growth but also the descent (or transition) is getting delayed due to the excess of soil moisture.

The study aims to address the start time of AT with Sodar data. Aloft, both SNR and $\boldsymbol{\sigma}$ identify the start of the AT around the same time, 120-160 min prior to the time of sunset, depending on the height considered. Aloft, SNR variation is robust in identifying the transition compared to ambiguous variations in horizontal wind velocity which decreases at lower altitudes and increases at higher altitudes. The start time of the AT as defined by different state variables shows some seasonal variation, with delayed transitions during the northeast monsoon at the surface and aloft.

\section{REFERENCES:}

1. Anandan, V.K., Shravan Kumar, M., Srinivasa Rao, I., 2008: 'First results of experimental tests of the newly developed NARL phased-array Doppler sodar'. Journal of Atmospheric and Oceanic Technology 25:1778-1784.

2. Taylor, P.A. \& Garratt, J.R. (1996). BoundaryLayer Meteorology. Netherlands: Kluwer Academic Publishers.

3. Stull, R. B.,1988: 'An Introduction to Boundary Layer Meteorology', 666 pp., Kluwer Acad., Norwell, Mass. 
4. Srinivasa Rao, I., Anandan, V.K., and Shravan, K.M., 2009: 'Multifrequency Decoding of a Phased Array Doppler Sodar', J. Atmos. Oceanic Technol. 26, 759-768.

5. Rao, T. N., Radhakrishna, B., Nakamura, K., and Prabhakara Rao, N., 2009: 'Differences in raindrop size distribution from southwest monsoon to northeast monsoon at Gadanki', Q. J. Roy. Meteorol. Soc., 135, 1630-1637.

6. Mehta, S.K., Ratnam, M.V., Sunil Kumar, S. V., Rao, D.N. \& Krishna Murthy, B. V. (2017). Diurnal variability of the atmospheric boundary layer height over a tropical station in the Indian monsoon region. Atmospheric Chemistry and Physics. [Online]. 17 (1). pp. 531-549. Available from: phys.net/17/531/2017/2.

7. Lothon, M., Lohou, F., Pino, D., Couvreux, F., Pardyjak, E. R., Reuder, J., Vilà-Guerau de Arellano, J., Durand, P, Hartogensis, O., Legain, D., Augustin, P., Gioli, B., Lenschow, D. H., Faloona, I., Yagüe, C., Alexander, D. C., Angevine, W. M., Bargain, E, Barrié, J., Bazile, E., Bezombes, Y., Blay-Carreras, E., van de Boer, A., Boichard, J. L., Bourdon, A., Butet, A., Campistron, B., de Coster, O., Cuxart, J., Dabas, A., Darbieu, C., Deboudt,K., Delbarre, H., Derrien, S., Flament, P., Fourmentin, M., Garai, A., Gibert, F., Graf, A., Groebner, J., Guichard, F., Jiménez, M.. A., Jonassen, M., van den Kroonenberg, A., Magliulo, V., Martin, S., Martinez, D., Mastrorillo, L., Moene, A. F., Molinos, F., Moulin, E., Pietersen, H. P., Piguet, B., Pique, E., Román- Cascón, C., Rufin-Soler, C., Saïd, F., Sastre-Marugán, M., Seity, Y., Steeneveld, G. J., Toscano, P., Traullé, O., Tzanos, D., Wacker, S., Wildmann, N., and Zaldei, A., 2014: 'The BLLAST field experiment: Boundary-Layer Late Afternoon and Sunset Turbulence', Atmos. Chem. Phys., 14, 1093110960, (doi:10.5194/acp-14-10931-2014).

8. Klein, P. M., Hu, X. M., and Xue, M., 2014: 'Impacts of mixing processes in nocturnal atmospheric boundary layer on urban ozone concentrations', Bound.-Lay. Meteorol., 150, 107-130,(doi:10.1007/s10546-013-9864-4).

9. Mahrt, L., 1981: The early evening boundary layer transition, Q. J. Roy. Meteor. Soc., 107, 329-343,

10. Van de Wiel, B. J. H., Moene, A. F., Steenveld, G. J., Baas, P.,Bosveld, F. C., and Holtslag, A. A. M.,2010: 'A conceptual view oninertial oscillations and nocturnal low-level jets', J.
Atmos. Sci.,67,

2679-2689,

(doi:10.1175/2010JAS3289.1).

11. Pino, D., Jonker, H. J. J., Arellano, J. V. G., and Dosio, A.,2006: 'Roleof shear and the inversion strength during sunset turbulence overland: characteristic length scales', Bound.-Lay. Meteorol., 121,537-556, (doi:10.1007/s10546006-9080-6).

12. Busse, J. and Knupp, K., 2012: 'Observed characteristics of the afternoon evening boundary layer transition based on sodar and surface data', J. Appl. Meteorol. Clim., 51, 571-582.

13. Brazel, A. J., Fernando, H. J. S., Hunt, J. C. R., Selvor, N.,Hedquist, B. C., and Pardyjak, E.2005: 'Evening transition observations in Phoenix, Arizona', J. Appl. Meteorol., 44, 99-112.

14. Edwards, J. M., Beare, R. J., and Lapworth, A. J., 2006: 'Simulation of the observed evening transition and nocturnal boundary layers: Singlecolumn modelling', Q. J. Roy. Meteor. Soc., 132, 61-80.

15. Pino, D., Jonker, H. J. J., Arellano, J. V. G., and Dosio, A., 2006: 'Roleof shear and the inversion strength during sunset turbulence overland: characteristic length scales', Bound.-Lay. Meteorol. , 121,537-556, (doi: 10. 1007/s10546006-9080-6).

16. Sorbjan, Z., 2007: 'A numerical study of daily transitions in the convective boundary layer', Bound.-Lay. Meteorol., 123, 365383,(doi:10.1007/s10546-006-9147-4).

17. Nadaeau, D. F., Pardyjak, E. R., and Higgins, C.W., 2011: 'A simple model for the afternoon and early decay of convective turbulence over different land surfaces', Bound.-Lay. Meteorol., 141, 301-324.

18. Sastre, M., Yague, C., Roman, C. C., Maqueda, G., Salamanca, F., and Viana, S., 2012: 'Evening transitions of the atmospheric boundary layers: characterization case studies and WRF simulations', Adv. Sci. Res., 8, 39-44.

19. Poulos, S. G., Blumen, W., Fritts, D. C., Lundquist, J. K., Sun, J.,Burns, S. P., Nappo, C., Banta, R., Newsom, R., Cuxart, J., Terradellas, E., Balsley, B., and Jensen, M., 2002: 'A comprehensive investigation of the stable nocturnal boundary layer', B. Am. Meteorol. Soc., $83,555-581$.

20. Fernando, H. J. S., Verhoef, B., Sabatino, S. Di., Leo, L. S., and Park, S., 2013: The Phoenix evening transition flow experiment(TRANSFLEX), Bound.-Lay. 
Meteorol. , 147, 443-468,(doi:10.1007/s10546012-9795-5).

21. Bonin, T., Phillip, C., Brett, Z., and Fedorovich, E., 2013: 'Observations of the early evening boundary-layer transition using a small unmanned aerial system', Bound.-Lay. Meteorol., 146, 119132.

22. Grimsdell, A. W. and Angevine, W. M., 2002: 'Observations of the afternoon transition of the convective boundary layer', J. Appl. Meteorol.,41, 3-11.

23. Rao, T. N., Kirankumar, N. V. P., Radhakrishna, B., Rao, D. N., and Nakamura, K., 2008: 'Classification of tropical precipitating systems using wind profiler spectral moments part I: algorithm description and validation', J. Atmos. Ocean. Tech., 25, 884897,(doi:10.1175/2007JTECHA1031.1).

24. Sandeep, A., Rao, T. N., Ramkiran, C. N., and Rao, S. V. B., 2014: 'Differences in atmospheric boundary-layer characteristics between wet and dry episodes of the Indian summer monsoon', Bound. Lay. Meteorol. , 153, 217-236, (doi: 10. 1007/s10546-014-9945-z). 